\title{
Impact of Currency Redenomination on an Economy: An Evidence of Ghana
}

\author{
Bright Obuobi ${ }^{1}$, Emmanuel Nketiah $^{1}$, Faustina Awuah ${ }^{2}$, Fredrick Oteng Agyeman ${ }^{1}$, Deborah Ofosu ${ }^{1}$, Gibbson \\ Adu-Gyamfi ${ }^{1}$, Mavis Adjei ${ }^{1} \&$ Adelaide Gyanwah Amadi ${ }^{1}$ \\ ${ }^{1}$ School of Business, Nanjing University of Information Science \& Technology, Nanjing 210044, China \\ ${ }^{2}$ University of Education, Winneba, Ghana \\ Correspondence: Bright Obuobi, School of Business, Nanjing University of Information Science \& Technology, \\ Nanjing 210044, China.
}

Received: December 6, 2019

Accepted: January 14, 2020

Online Published: January 16, 2020

doi:10.5539/ibr.v13n2p62

URL: https://doi.org/10.5539/ibr.v13n2p62

\begin{abstract}
The main objective of this study is to ascertain the impact of currency redenomination on the Ghanaian economy. Since independence in 1957, Ghana has had series of redenomination exercises but the recent one which became a debatable topic happened in 2007. As a result, the study is conducted to determine the pre and post-performance of the country using 2007 as the benchmark. This research takes into consideration the quantitative research technique based on ex-post factor design. Secondary data of the research variables (GDP, Economic growth, Balance of trade, inflation, FDI and Globalization index) were used over a 20-year period between 1997 and 2017. Analytical techniques of both descriptive statistics and independent sample test were used for the research. The t-test for equality of means adopted was to determine the statistically significant difference on the economic variables. The study also used the Levene's test of equality of variance assumed. It was concluded that, currency redenomination is beneficial to an economy's growth. It was therefore recommended that, the government of Ghana initiates policies that will boost local production to support the exercise so as to increase GDP and other associated economic variables.
\end{abstract}

Keywords: redenomination, currency, Ghana, globalization, inflation, economic growth

\section{Introduction}

\subsection{Background of the Study}

Since the 1960s, governments of developing and transition economies have redenominated their currencies on approximately seventy occasions (Mosley, 2005).

Redenomination can be described as the process by which the currency of a country made anew as a result of substantial inflation and currency devaluation. In the course of the exercise, a specific number of zeroes is cancelled from the currency. This exposes everything that is expressed through the national currency to the new monetary scale arrived at. It goes a long way to involve all amounts and transactions in the economy such prices of goods and services rendered in the nation, wages and salaries, savings, pensions, debts, rents, and other payment commitments, exchange rate and taxes, among others (Venezuela, 2008, p9).

Redenomination as a governmental policy isn't new to the world. Throughout the world, there has been various redenomination exercises taking place in some countries. Zimbabwe as a country experienced three redenomination exercises within four years (2006, 2008 and 2009). In 2018, São Tomé and Príncipe redenominated their currency as well as a means of reducing inflation. Other countries that implemented this exercise in the last decade include; Turkmenistan and Slovakia who redenominated their currencies in 2009, Malta, Venezuela (2008) and Mozambique also had theirs in 2008 though Mozambique had implemented the exercise before in 2006, Ghana which happens to be the country understudy implemented the policy in 2007 same as Sudan. Azerbaijan and Slovenia also did it 2006, whiles Turkey and Romania implemented it in 2005 (Wikipedia.org).

This is a clear indication that, redenomination exercise has some potential influence on an economy and the citizenry, but the actual effect remains an empirical one. While redenomination decisions and currencies design may seem more technical than political, a government's control and administration of its currency predicaments 
and transactions within its boundaries is very essential. Although such monetary control started in the 1850 s, the main struggle currently is still to maintain this mentioned control, specifically in the face of civil issues or economic breakdown (Woodruff, 1990).

According to Mosley (2005), the reasons why some countries decide to redenominate their currency are combination of economic and political factors such as inflation, government concerns about credibility and the effect of currency on national identity. Mosley (2005) also stated that the redenomination is also related to other political variables such as government time horizons, the governing party's ideology, the fractionalization of government and legislature and the degree of social heterogeneity.

Specifically, though it is not exhaustive, inflationary pressures, psychological effect, control of currency substitution and domestic politics are identified as the main reasons of redenomination (Cohen, 2004; Tarhan, 2006). Suhendra and Handayani (2012) suggested that removing zeros from currency is a complementary component of policy stabilization and it will have positive physiological effects on restoring the credibility of the currency in question.

Redenomination of currency may also reflect governments' effort to reassert restructure monetary control. If citizens of a country lose trust in the national currency, they would use foreign currencies as in the case of Zimbabwe, particularly for those with higher prestige. In reference to this assertion, (Cohen 2004) explained that, this can be both a psychological and an economic knock to the government with widespread foreign currency substitution, central bank no more control the money supply, making it unable to provide last resort lender functions. As a consequence, redenomination usually follows economic crises as governments and authorities try to persuade citizens and investors that hyperinflation is a cliché. In some cases, if the timing is correct for the redenomination exercise, it will reduce high levels of inflation. In other cases, policymakers are unable to record excellent numbers in inflation immediately after redenomination and may result in making multiple efforts towards currency reform (Zimbabwe 2006, 2008, 2009, Argentina and Brazil during the 1980s and early 1990s) are common examples (Mosley 2005). Currency redenomination may also pose a false resolution of the monetary illusion problems associated with numerous zeros and the resulting loss of currency credibility because there is a false sense of abundance with inflation as monetary units grow higher.

According to Özçay (2006), the removal of zeros from the Turkish Lira has eliminated both technical and operational problems resulting from the use of multiple zero figures, therefore, monetary expressions have been simplified making records keeping easier and reducing volumes of transactions. In addition, he said, the redenomination of the Old Turkish Lira to the New Turkish Lira was necessary both for the prospective positive effects on the currency's reputation and for technical reasons. He also stated that, eliminating six zeros from the Turkish Lira has contributed not only to the prestige of the currency in the eyes of Turkish citizens but also globally.

Redenomination was used in approximately 50 countries as a process that helped to decrease the nominal value of a currency as emphasized by Ioana, 2005. It was usually used as one of the steps used in stabilizing an economy on which various policies are built upon. For instance, redenomination took place in Poland and Bulgaria after their stabilization programmes proved successful. Also, in Turkey, redenomination was first considered in 1998, but at that time inflation was still running high at an increasing rate. The parliament of Turkey then passed a law to remove six zeros from their previous currency to create a new currency called the New Turkish Lira in December 2003 (Libor Žídek Michal Chribik 2015).

\subsection{Overview of Ghana's Currency}

Before Ghana's Independence, the official legal tender in the country was the West African pounds, shillings and pence. In 1958, the country outdoor its first national currency, that is Ghana pounds, shillings and pence. In the mid-1960s, Ghana bid a farewell to the colonial monetary system by introducing the Cedi. The cedi is the official currency of Ghana which is subdivided into pesewa. Hundred pesewa makes one cedi. The word "cedi" is derived from an Akan (a Ghanaian indigenous language) word "sidie" which refers to cowry shells, a 19th Century medium of exchange in Ghana. The name "pesewa" also emerged from a former medium of exchange in Ghana which was referred the least quantity of gold dust. This is because in ancient times the shells were used as a form of money and it gained popularity and wider circulation in the later part of the nineteenth century (Bank of Ghana, 2000).

\subsection{Statement of the Problem and Objective}

When the news out broke that there was going to be a new currency to be used, many local and foreign individuals and organizational bodies expressed dissatisfaction towards the exercise. It created a lot of 
controversy between the governing body and the citizenry. An intense education was made in the country on the benefits of the redenomination by the Bank of Ghana and the media. Amidst the challenges and moving forward, Ghanaians slowly adapted to the change and fully accepted the new Ghana Cedis. However, it has been over ten years and few individuals especially market men and women still pronounce the old Cedis even though they are transacting with the new Ghana Cedis. This proves the problems encountered by many citizens as far as the exercise in concerned.

Based on these problems Amoako-Agyeman and Mintah (2014) wrote that, petty traders, taxi drivers, newspaper vendors, food sellers and other businesses of that category could be inconvenienced with lack of change. They were of the view that, it could result in frequently rounding off and consequently increasing inflation. Another major problem cited by them was lack of adequate education or preparation prior to the redenomination of the cedi to the general public.

Whilst the ordinary Ghanaian was looking at the immediate impact of the redenomination exercise, the Bank of Ghana was looking at both the short- and long-term impact. One major reason of the exercise was to curb inflation and increase the value of the Ghanaian currency to be at par with the foreign dominant currency. Ten years along the lane, various policies have been implemented and has been discussed and argued by politicians, scholars and analysts. In these ten years after the redenomination exercise, Ghana has undergone various ups and downs as far as economic indicators are concerned. This calls for the need to access the pre and post redenomination period to determine whether or not the redenomination exercise implemented by the Central government of Ghana in 2007 has helped Ghana in the global competitive market in the long run.

Due to this, the impact of the exercise on the Ghanaian economy remain empirical that need to be studied. Hence the objective of the study is to determine the impact of redenomination of the Ghanaian currency on the Ghanaian economy using economic variables.

\section{Literature Review}

The cedi was first introduced on July 19, 1965 to February 22, 1967 to replace the Ghana pound, shilling and pence which were the first currency introduced by the Bank of Ghana after the independence of the country from British rule for the purpose of decimalization. The first cedi replaced the pound at a rate of 2.4 cedi $=1$ pound, or 1 pesewa = 1 penny. The "first" cedi bank notes were issued in denomination of 1, 5, 10, 50, 100 and 1000 cedi notes. Except the 1000 cedi note, all the denominations bore the portrait of Dr. Kwame Nkrumah; Ghana's first president after independence from British rule (Wikipedia).

The "first" cedi coins on the other hand were issued in denomination of 5 pesewas, 10 pesewas, 25 pesewas and 50 pesewas. Smaller coin denominations below the 5 pesewas were not issued. This was because the $1 / 2$ penny and 1 penny which were in circulation since the colonial days were made to exist as $1 / 2$ pesewa and 1 pesewa respectively. All the coins issued bore the portrait of Dr. Kwame Nkrumah (Bank of Ghana, 2000).

Two years later, another cedi was introduced. This replaced the 1965 cedi at a rate of $\phi 1.20=\mathrm{N} \phi 1.00$. The motive behind this change was partly economic and political: convenience of exchange that is the change allowed for an easier conversion from the Ghana cedi to pound (Schuler, 2008).

The change resulted in the removal of Dr. Kwame Nkrumah's portrait from the coins and notes. This was after Nkrumah's government was toppled in a military coup d'état in 1966.The second cedi notes were initially issued in 1967 in denominations of 1, 5, and 10 cedi notes. In 1972 and 1973 a second series of the New ("second") cedi denominations were issued in 1, 2, 5, and 10 cedi notes. Then another (third) series of issue of the cedi was done in 1979 which consisted of 1, 2, 5, 10, 20 and 50 cedi notes. In 1983, another new series of the second cedi bank note were issued in denomination of 10, 20, 50, 100 and 200 cedi notes (Wikipedia).

Later there were higher denominated bank notes which were 500 cedi note (in 1986), 1000 cedi note (in 1991), 2000 cedi note (in 1995), 5000 cedi note (in 1996) and 10,000 and 20,000 (in 2002). The "second" cedi coins were initially introduced in denominations of $1 / 2,1,2.5,5,10$ and 20 pesewa(s). In 1979, coins of 50 pesewas and 1 cedi denominations were introduced. By the end of the 1980s all these denominations have fallen out of circulation due to inflation. Further, in 1991 10, 20, 50, and 100 cedi coins of the second cedi were introduced and in 1996 a 200 and 500 cedi coins were also made to circulate (Bank of Ghana, 2000).

In 1979, a currency confiscation took place. There was the issuance of new banknotes which saw citizens exchanged 10 old for 7 new (Schuler, 2008). Ghana's currency devalued many times in the early 1980s and the adoption of International Monetary Fund Structural Adjustment Programs could be traced as a part of the contributing factors. Ghana joined the Enhanced Highly Indebted Poor Country (HIPC) initiative in 2001, which is debt-relief collaboration between the IMF and the World Bank (Bargawi, 2004). This operation ended with a 
free cedi float against foreign currencies in early 1990s. Inflation continued until by July 2007, the cedi was worth about 9500 to one US dollar, this brought to the third cedi (Bank of Ghana, 2007).

In November 2006, an initiation towards the re-denomination of the cedi by the central bank of Ghana had been put place. A third cedi emerged, worth 10,000 of the old Cedis. With this, the cedi was not devaluated nor re-valued but only redenominated. Because of this change, Ghana's currency became one of the highest-valued currency units from one of the least valued currency units (Bank of Ghana, 2007).

For the effectiveness and easier implementation of the exercise, the Bank of Ghana (BOG) developed some guidelines to be followed by businesses in converting to the Ghana Cedi. Other stakeholders, such as the Institute of Chartered Accountants, the Securities and Exchange Commission and the Ghana Stock Exchange, were expected in due course to issue further guidelines and clarifications to help financial reporting. (Price waterhouse Coopers 2007).

Both the old and new currencies were in circulation for a period of six months, businesses had to develop systems to handle both currencies over that period in their accounting records. One option was to set up and define the Cedi (old currency) as another foreign currency in the financial management systems that support multi-currency. With this, data can be captured in both currencies with minimal data entry errors. (Price waterhouse Coopers 2007).

\subsection{Reasons for the Redenomination of the Cedi by Bank of Ghana}

Countries don't just redenominate overnight. There are many reasons and guided motivation why a country may decide to redenominate her currency ranging from credibility and identity, to domestic and international politics (International Monetary Fund, 2003; Mosley, 2005; Martinez, 2007).

The BOG press released on the redenomination of the cedi (Daily graphic, 2007), stated the following reasons that necessitated the redenomination.

(1) Simplification of accounting records and the ease of expressing monetary values

(2) Re-introduction of the culture of using coins which will reduce pressure on bank notes

(3) Significant reduction in transaction volumes

(4) Seduction in the cost of carrying large volumes of bank notes and its associated risks.

(5) Efficiency in payment systems such as the use of ATMs

(6) Facilitating the introduction of the use of vendor machines and car parking meters

(7) Promoting tourist expenditures

(8) Significant cost savings to the BOG in the cost of printing bank notes.

Ghana cedi note (Bank of Ghana, 2007).

In reference to these reasons given, Acquah (2007), wrote that, the re-denomination will deal with the inefficiencies associated with the old currency. Again the inconveniences and risk involved in carrying loads of currency for transaction purpose, the deadweight burden of the current cedi denominations, the increasing difficulties in maintaining bookkeeping and statistical records, incompatibility with data processing software and the strain on the payments system particularly the ATM in an economy are some of the reasons for the redenomination (Bank of Ghana, 2007).

Various scholarly and empirical analysis has suggested that re-denominations has been very successful in an environment of macroeconomic stability. The declining inflation, stable exchange rate, fiscal prudence and well-anchored expectations of policy credibility call for the re-denomination by stripping the prices and values of the numbers that the force of inflation has embedded in them, put a hard-wire around all these economic changes and measures and lift the dead weight burden the existing note regime places on the economy (Addison 2007).

Another reason is that, the re-denomination will free the economy to do business in the most efficient way, based on the cedi as a means of exchange; and with continued commitment to prudent and disciplined economic policies, which will serve as a store of value for all, both within and outside of the banking system (Daily graphic, 2007).

According to Bank of Ghana (2007), factors such as the expansion of the payment system have not only made the currency of the country unattractive but have also diminished its reliability as a store of value, which needs a reform. The bank then took advantage of the current stable macroeconomic setting, which was reflected in declining inflation rates, relative price stability, a stronger growth in Gross Domestic Product, stable exchange 
rates, and an increase in Gross International Reserves to enforce the redenomination. The re-denomination of Ghanaian currency would also help to reduce the increasing rate of pick pocketing and armed robbery cases in the country. Ghana joined the League of Nations whose currencies are well recognized and highly valued in the world (Bank of Ghana, 2007).

\subsection{Challenges Associated with the Redenomination}

Redenomination is not a challenge-free policy because in policy there is a price to pay to make it successful. Redenomination comes with its challenges which include; issues associated with rescaling, cost involve in disposing off the old notes and coins, cost associated with citizenry education, enlightenment and advertisement of the change to citizens, etc. (Bank of Ghana, 2007). There are challenges that came with the redenomination exercise, notwithstanding the fact that the market women also came out with some benefits of the redenomination (Amoako-Agyeman \& Mintah 2014). Challenges contrary to the belief that the re-denomination is a simple exercise, it is believed that the exercise poses significant challenges to businesses because business organizations have enormous cost consequences. A significant part of the cost will be one off, but there are other costs which will continue to be incurred until the current currency is completely withdrawn (Price water house Coopers 2007).

The costs include:

- Upgrade or re-configuration of business and accounting software

- Organizational Staff training

- Costs associated with adjustments in business policies and practices

- Cost of printing new stationery (invoices, receipt books, cheque books, etc.)

- Cost associated with ensuring timely accurate data collection in both currencies

(Price Water house Coopers 2007).

Also, a study by Amoako-Agyeman \& Mintah (2014) revealed that, majority of the market women faced challenges in using the new currency when it was first introduced. He added that, One major challenge was exchanging the GHc50 (highest note) into smaller units particularly when customers bought goods from them. In addition to the same study, customers as well as the market women sometimes reject the GHc50 as medium of exchange for the fear of loss if get missing or counterfeited. Their study also showed that, the market women experienced some difficulties with the least denomination, which is the GHp1, because customers usually refuse to accept it for a change due to its smaller size. Another challenge pointed out by the study was the fewer circulation of the coins in the economy, making it difficult to buy items that have lower prices and expressed in those terms. Finally, their study revealed that, the market women had serious problem differentiating counterfeit notes from the real notes.

\section{Definition of Variables}

\subsection{Economic Growth}

Economic growth represents an increase in inflation-adjusted market value of goods and services produced over time by an economy. It is measured as the percent rate of increase in real GDP. An economy can experience an intensive or extensive growth. Intensive growth is referred to as increased economic growth due to a more productive use of inputs (increasing labour productivity, physical capital, energy or materials). Extensive growth on the other hand is due to only increased of inputs for use (growing population, new territory).

\subsection{Gross Domestic Product (GDP)}

GDP is the aggregate monetary or market value for all finished goods and services that are produced within a country in a particular period of time. It is an important tool for nations because it serves as a comprehensive scorecard and yardstick for economies as an overall domestic production and status. GDP can be measured in nominal terms which is the measurement of the raw data. It can also be referred to in real terms which takes into consideration the impact of inflation and create room for year-to-year comparisons of economic output and other comparisons over time.

\subsection{Foreign Direct Investments (FDI)}

Foreign Direct Investment (FDI) is an investment made in business interests located in another country by a company or individual in one country. In general, FDI occurs when an investor creates foreign business or acquires foreign business assets in a foreign corporation. FDIs are, however, distinct from portfolio investments in which an investor only buys foreign-based companies' equities. Foreign direct investment is commonly made 
in open economies that provide the investor with skilled labour and above-average growth prospects, as opposed to tightly regulated economies. It often involves more than just a capital investment. It can also include management or technology provisions. The main feature of foreign direct investment is that, it ensures either effective control over the decision-making of a foreign business, or at least substantial influence.

\subsection{Balance of Trade to GDP}

Trade balance is the sum of the exports of a nation minus their imports. It is the current account's most important component. This also makes it the largest balance of payments component which measures all international transactions. As a result, most countries are attempting to develop trade policies that promote a trade surplus. A surplus is often seen as a favorable balance of trade because it is just like making a profit in a business but in this case as a country. Most countries around the globe prefer selling more products and receiving more capital for their residents to buying. This implies a higher standard of living for the citizens of the countries. By producing all their exports, there is a competitive advantage achieved by their companies in terms of competence and expertise. They recruit more workers which tend to lower unemployment and generate more income. Depending on whether or not a country improves its business cycle, a trade deficit may sometimes denote a favorable balance of trade. But in most cases, trade deficits reflect an unfavorable balance of trade.

\subsection{Inflation}

Inflation is a quantitative measure of the rate at which an economy's prices of goods and service increase over time. It is the steady rise in the overall price rate where a currency unit purchases less than it did in previous times. A single currency unit loses value as prices rise and it buys less goods and services. This loss of purchasing power has an impact on the general cost of living for the general public that eventually leads to a slowdown in economic growth. Economists' consensus view is that sustained inflation occurs when economic growth is outpaced by the money supply of a country.

\subsection{Globalization}

In order to quantify the growth effects of globalization the KOF Index of Globalization aimed at measuring the rate of Globalization in countries around the world. The index is based on three dimensions: economic, social, and political. Through these three dimensions, globalization's overall index aims to evaluate current economic flows, economic constraints, information flow data, personal contact data, and cultural proximity data within surveyed countries.

\section{Methodology}

\subsection{Data Source}

The study adopts quantitative research technique based on ex-post facto design. It uses secondary data on the research variables (Gross Domestic product, Economic growth, Balance of trade, Inflation, FDI and globalization) over the period 1997 to 2017. Data were sourced from the annual World Bank and the Central Bank of Ghana (BoG) reports. Though Ghana has had various redenomination exercises but for the purpose of this study, the 2007 exercise was used as the basis of assessment.

Time period (Pre-redenomination $)=1997-2006=10$

Time period (Post redenomination) $=2008-2017=10$

The 2007 year is excluded because it is used as the base year when the exercise was implemented. As a result, data for 2007 is omitted.

\subsection{Hypothesis}

The null hypothesis represented by $\left(\mathrm{H}_{0}\right)$ and alternative hypothesis also denoted by $\left(\mathrm{H}_{1}\right)$ of the Independent Samples $t$ Test can be expressed in two different but equivalent ways:

$H_{0}: \mu_{1}=\mu_{2}$ ("the two population means are equal")

$H_{1}: \mu_{1} \neq \mu_{2}$ ("the two population means are not equal")

\subsection{Research Method}

For the analysis, quantitative methods are adopted for both descriptive statistics and independent sample testing. The t-test was used to ascertain evidence of statistically significant difference in banking sector performance indicators (Gross Domestic product, Economic growth, balance of trade, Inflation, FDI and Globalization) between pre and post-redenomination periods. The test of Equal variances assumed was also adopted for the study. 


\subsubsection{Levene's Test for Equality of Variances}

The independent Samples t Test requires the assumption of homogeneity of variance that is both groups have the same variance. A test for the homogeneity of variance, called Levene's Test.

The hypotheses for Levene's test are:

$H_{0}: \sigma_{1^{2}}-\sigma_{2^{2}}=0$ ("the population variances of group 1 and 2 are equal")

$H_{1}: \sigma_{1^{2}}-\sigma_{2^{2}} \neq 0$ ("the population variances of group 1 and 2 are not equal")

The above implies that, if the null hypothesis of Levene's Test is rejected, then the variances of the two groups are not equal. It simply means the homogeneity of variances assumption is violated.

\subsubsection{Test Statistic}

The test statistic for the Independent Samples Test is denoted by $t$. For the purpose of this study there are actually two forms of the test statistic for this test based on the equal variances assumed.

\subsubsection{Equal Variances Assumed}

When the two independent samples are assumed to be drawn from populations with identical population variances (i.e., $\sigma_{1^{2}}=\sigma_{2^{2}}$ ), the test statistic $\mathrm{t}$ is calculated as:

$$
t=\frac{\bar{x}_{1}-\bar{x}_{2}}{s_{p} \sqrt{\frac{1}{n_{1}}+\frac{1}{n_{2}}}} \ldots \ldots \ldots \ldots \ldots \ldots \ldots \text {. Eqn }
$$

with

$$
s_{p}=\sqrt{\frac{\left(n_{1}+1\right) S_{1}^{2}+\left(n_{2}+1\right) S_{2}^{2}}{\left(n_{1}+n_{2}-2\right)}} \ldots \ldots \ldots \ldots \ldots \ldots \ldots \ldots \ldots \ldots \text { Eq }
$$

Where:

$\bar{x}_{1}=$ Mean of first sample

$\bar{x}_{2}=$ Mean of second sample

$n_{1}=$ Sample size (that is number of observations) of first sample

$n_{2}=$ Sample size (that is number of observations) of second sample

$s_{1}=$ Standard deviation of first sample

$s_{2}=$ Standard deviation of second sample

$s_{p}=$ Pooled standard deviation

\subsubsection{Equal Variances Not Assumed}

When the two independent samples are assumed to be drawn from populations with unequal variances (i.e., $\sigma_{1^{2}} \neq \sigma_{2^{2}}$ ), the test statistic $\mathrm{t}$ is calculated as:

$$
t=\frac{\bar{x}_{1}-\bar{x}_{2}}{s_{p} \sqrt{\frac{1}{n_{1}}+\frac{1}{n_{2}}}} \ldots \ldots \ldots \ldots \ldots \ldots \ldots \ldots q n
$$

Where:

$\bar{x}_{1}=$ Mean of first sample

$\bar{x}_{2}=$ Mean of second sample

$n_{1}=$ Sample size (that is number of observations) of first sample

$n_{2}=$ Sample size (that is number of observations) of second sample

$s_{1}=$ Standard deviation of first sample

$s_{2}=$ Standard deviation of second sample 
The calculated $t$ value is then equated to the critical $t$ value from the $t$ distribution table with degrees of freedom

$$
d f=\frac{\left(\frac{S_{1}^{2}}{n_{1}}+\frac{S_{2}^{2}}{n_{2}}\right)}{\frac{1}{n_{1}-1}\left(\frac{S_{1}^{2}}{n_{1}}\right)^{2}+\frac{1}{n_{1}-2}\left(\frac{S_{2}^{2}}{n_{2}}\right)^{2}} \ldots \ldots \ldots \ldots \ldots \ldots \ldots \ldots \ldots \ldots \ldots n
$$

\section{Results and Discussion}

Table 1. General descriptive analysis

\begin{tabular}{|l|l|l|l|l|l|l|}
\hline Variables & $\mathrm{N}$ & Minimum & Maximum & Mean & Std. Deviation & Variance \\
\hline GDP $(\$ \mathrm{bn})$ & 20 & 4.9800 & 63.280 & 26.7230 & 20.8909 & 436.429 \\
\hline $\begin{array}{l}\text { Economic } \\
\text { growth }\end{array}$ & 20 & 0.0218 & 0.1405 & 0.0589 & 0.0278 & 0.001 \\
\hline Inflation rate & 20 & 0.067 & 0.329 & 0.1643 & 0.0656 & 0.004 \\
\hline $\begin{array}{l}\text { BOT per } \\
\text { GDP }\end{array}$ & 20 & -0.2580 & -0.0313 & -0.1480 & 0.0594 & 0.004 \\
\hline FDI per GDP & 20 & 0.0096 & 0.0952 & 0.0464 & 0.0292 & 0.001 \\
\hline $\begin{array}{l}\text { Globalization } \\
\text { index }\end{array}$ & 20 & 46.54 & 61.46 & 54.8355 & 3.9365 & 15.496 \\
\hline
\end{tabular}

Table 1 above shows a general descriptive statistic of the variables used in Ghana. The table reveals results of Mean, max and Min, Standard deviation and variance for GDP, Economic growth, Inflation rate, balance of Trade, Foreign direct investment and Globalization index. In the 20 year period under study, the mean value for GDP for the Ghanaian economy is $\$ 26.723$ billion with a minimum and maximum of $\$ 4.98$ billion and $\$ 63.280$ billion respectively. The variance stood at 436.429 as can be seen from the (table 1).

Economic growth measured in percentage recorded a 20-year mean value of 0.0589 with a minimum of 0.0218 and a maximum of 0.1405 . A variance of 0.001 was recorded within the 2 decades. Inflation which measured the increment of prices of goods and services expressed as a percentage revealed a 0.1643 mean value. Ghana's inflation according to the table experienced a maximum value of 0.329 and a minimum of 0.067 with a variance of 0.004 within the period.

The difference between Ghana's total exports and imports referred to as the Balance of Trade had a mean value of -0.1480 during the period. A maximum and minimum values of 0.0313 and -0.2580 respectively were recorded. It recorded the same variance value as the inflation, which is 0.004 .

The mean value for Foreign Direct investments for the Ghanaian economy stood at 0.064 with a maximum and minimum value of 0.0952 and 0.0096 respectively. A lower variance value of 0.001 was recorded. Finally, the table gives results for Globalization index and the mean value for Ghana within the 20-year period is 54.8335. Its variance was 15.496 but had a maximum and minimum value of 61.46 and 46.54 respectively.

Tables 2. Group Statistics

\begin{tabular}{|l|l|l|l|l|l|}
\hline Variables & Period & $\mathrm{N}$ & Mean & Std. Deviation & Std. Error Mean \\
\hline \multirow{3}{*}{ GDP $(\$$ bn $)$} & Pre & 10 & 8.620 & 4.4698 & 1.4135 \\
\cline { 2 - 6 } & Post & 10 & 44.826 & 13.1570 & 4.1606 \\
\hline \multirow{2}{*}{$\begin{array}{l}\text { Economic } \\
\text { growth }\end{array}$} & Pre & 10 & 0.0486 & 0.0088 & 0.0028 \\
\cline { 2 - 6 } & Post & 10 & 0.0692 & 0.0364 & 0.0115 \\
\hline \multirow{2}{*}{ Inflation rate } & Pre & 10 & 0.1954 & 0.0735 & 0.0233 \\
\cline { 2 - 6 } & Post & 10 & 0.1332 & 0.0392 & 0.0124 \\
\hline
\end{tabular}




\begin{tabular}{|l|l|l|l|l|l|}
\hline BOT per GDP & Pre & 10 & -0.1843 & 0.0464 & 8.0147 \\
\cline { 2 - 6 } & Post & 10 & -0.1117 & 0.0487 & 0.0154 \\
\hline \multirow{2}{*}{ FDI per GDP } & Pre & 10 & 0.02039 & 0.0088 & 0.0028 \\
\cline { 2 - 6 } & Post & 10 & 0.07230 & 0.0150 & 0.0048 \\
\hline $\begin{array}{l}\text { Globalization } \\
\text { index }\end{array}$ & Pre & 10 & 52.0340 & 3.0444 & 0.9627 \\
\cline { 2 - 6 } & Post & 10 & 57.6370 & 2.4502 & 0.7748 \\
\hline
\end{tabular}

Table 2 shows the group statistics for the pre and post redenomination period. Taking GDP into consideration from the table above, the pre period experienced an increase. The result shows an increase in the performance GDP in the Ghanaian economy from a mean of 8.620 billion to $\$ 44.826$ billion for the pre and post capitalization periods respectively. The observed increment in GDP suggests an evidence of a better monetary policy in the post redenomination period (Table 2). This implies an improvement in Gross Domestic products of the Ghanaian economy after the redenomination exercise.

The next variable analyzed is the overall economic growth. The Ghanaian economy's growth recorded a mean value of 0.0486 and 0.0692 in the pre and post redenomination periods respectively. The result shows an increase in the economic growth of the Ghana. The observed increment Economic growth suggests an evidence of a better monetary policy in the post redenomination period (Table 2). This also implies an improvement of the Ghanaian economy after the redenomination exercise.

Inflation which happens to be the major factor of redenomination exercise was also analyzed descriptively. The result showed a decrease of Ghana's inflation rate from $19.54 \%$ to $13.32 \%$ mean values. This observed reduction of the inflation rate suggests an evidence of a better monetary policy in the post redenomination period (Table 2). This implies an improvement of the Ghanaian economy after the redenomination exercise.

Ghana's economy has experienced a series of negative balance of payment. This means Ghana's imports normally exceeds its exports resulting in the successive deficits. Just like the other variables, the Balance of Ghana's trade statistics are sown on the (Table 2). It however shows negative balances for both periods under study. The deficit was however reduced from -0.1843 to -0.1117 for the pre and post periods respectively indicating an overall improvement. This observed reduction of Ghana's trade deficit is an evidence of a better monetary policy in the post redenomination period (Table 2). This also implies an improvement in Ghana's trade balance after the redenomination exercise.

Foreign Direct Investments which is related to a country's openness to trade and investors was also analyzed. A country with unstable or devalued currency is less likely to attract foreign investment. In the respective periods, the descriptive statistics shows an FDI mean values of 0.02039 and 0.07230 . The increment of 0.05191 between the pre and post redenomination exercise is an evidence of improved foreign direct investment for Ghana. This increment of Ghana's FDI is an indication of a better monetary policy in the post redenomination period (Table 2). This also signifies an improvement in Ghana's trade balance after the redenomination exercise.

Finally, the KOF Index of Globalization which aimed at measuring the rate of Globalization in countries around the world was also descriptively analyzed to indicate how globalized the Ghanaian economy has been within the 2 decades. The result from the table shows an increment of the mean values from 52.0340 to 57.6370 for the pre and post periods respectively. This increment of the index is an indication that Globalization in Ghana has improved which is a good thing for the economy. This also signifies an improvement of Ghana's economy after the redenomination exercise.

\section{Independent sample test of equality of means}

An independent sample test of equality of means follows as shown in (Table 3). This is conducted to determine evidence of significant difference between the pre- and post- redenomination means. The level of significance is pegged at $5 \%$ level, thus, $(\mathrm{p}<0.05)$. For GDP, the result shows that at 5 per cent level of significance, there is a significant difference between pre- and post-redenomination means of GDP $(\mathrm{p}(0.000<0.05))$. This is an indication that, null hypothesis of no statistical significance is rejected (Table 2). For Economic growth variable, the result shows that at 5 per cent level of significance, there is a significant increase between pre and post-redenomination means of GDP $(\mathrm{p}(0.09>0.05))$. The null hypothesis of no statistical significance is accepted (Table 3). Inflation rate recorded a statistical mean difference of 0.03 . The results shows that at a 5 percent level of significance, there is a significant reduction between the pre and post redenomination means of 
Inflation ( $\mathrm{p}(0.03<0.05))$. The null hypothesis of no statistical difference is therefore rejected.

Balance of trade also showed a 0.003 statistical mean difference which is less than the level set beforehand. The results indicate that at a 5 percent level of significance, there is a significant reduction of Ghana's trade deficit between the pre and post redenomination means of Balance of trade $(p(0.003<0.05))$. The null hypothesis of no statistical difference is thereby rejected. Foreign Direct investments recorded a statistical mean difference of 0.000 . This result shows that at 5 per cent level of significance, there is a significant difference between pre, and post-redenomination means of FDI $(\mathrm{p}(0.000<0.05))$. This means that null hypothesis of no statistical significance is rejected (Table 2). The Last variable, Globalization index also shows a 0.000 mean value of statistical difference. This results shows that at 5 per cent level of significance, there is a significant increment between pre and post-redenomination means of Globalization $(\mathrm{p}(0.000<0.05))$. The null hypothesis of no statistical significance is therefore rejected (Table 3).

Table 3. Independent Samples Test

\begin{tabular}{|c|c|c|c|c|c|c|c|c|c|c|}
\hline & \multicolumn{2}{|c|}{$\begin{array}{lr}\text { Levene's Test for } \\
\text { Equality } & \text { of } \\
\text { Variances } & \\
\end{array}$} & \multicolumn{7}{|c|}{ t-test for Equality of Means } \\
\hline & & \multirow[t]{2}{*}{$\mathrm{F}$} & \multirow[t]{2}{*}{ Sig. } & \multirow[t]{2}{*}{$\mathrm{t}$} & \multirow[t]{2}{*}{ df } & \multirow[t]{2}{*}{$\begin{array}{l}\text { Sig. } \\
\text { (2-tailed) }\end{array}$} & \multirow[t]{2}{*}{$\begin{array}{l}\text { Mean } \\
\text { Difference }\end{array}$} & \multirow[t]{2}{*}{$\begin{array}{l}\text { Std. Error } \\
\text { Difference }\end{array}$} & \multicolumn{2}{|c|}{$\begin{array}{l}\text { Confidence Interval of } \\
\text { the Difference } 95 \%\end{array}$} \\
\hline & & & & & & & & & Lower & Upper \\
\hline \multirow[t]{2}{*}{ GDP (\$bn) } & $\begin{array}{l}\text { Equal } \\
\text { variances } \\
\text { assumed }\end{array}$ & 15.483 & 0.001 & -8.24 & 18 & .000 & -36.206 & 4.394 & -45.4378 & -26.974 \\
\hline & $\begin{array}{l}\text { Equal } \\
\text { variances } \\
\text { not } \\
\text { assumed }\end{array}$ & & & -8.24 & 11.050 & 0.000 & -36.206 & 4.394 & -45.872 & -26.540 \\
\hline \multirow[t]{2}{*}{$\begin{array}{l}\text { Economic } \\
\text { growth }\end{array}$} & $\begin{array}{l}\text { Equal } \\
\text { variances } \\
\text { assumed }\end{array}$ & 10.547 & .004 & -1.74 & 18 & .098 & -0.021 & 0.012 & -0.047 & 0.004 \\
\hline & $\begin{array}{l}\text { Equal } \\
\text { variances } \\
\text { not } \\
\text { assumed }\end{array}$ & & & -1.74 & 10.056 & .112 & -0.021 & 0.012 & -0.047 & 0.006 \\
\hline \multirow[t]{2}{*}{ Inflation rate } & $\begin{array}{l}\text { Equal } \\
\text { variances } \\
\text { assumed }\end{array}$ & 6.405 & .021 & 2.360 & 18 & .030 & .062200 & .026357 & .006827 & .117573 \\
\hline & $\begin{array}{l}\text { Equal } \\
\text { variances } \\
\text { not } \\
\text { assumed }\end{array}$ & & & 2.36 & 13.726 & .034 & .062200 & .026357 & .005565 & .118835 \\
\hline \multirow[t]{2}{*}{$\begin{array}{ll}\text { BOT } & \text { per } \\
\text { GDP } & \end{array}$} & $\begin{array}{l}\text { Equal } \\
\text { variances } \\
\text { assumed }\end{array}$ & 0.004 & 0.951 & -3.41 & 18 & .003 & -0.073 & 0.021 & -0.117 & -0.028 \\
\hline & $\begin{array}{l}\text { Equal } \\
\text { variances } \\
\text { not } \\
\text { assumed }\end{array}$ & & & -3.41 & 17.959 & .003 & -0.073 & 0.021 & -0.117 & -0.028 \\
\hline FDI per GDP & $\begin{array}{l}\text { Equal } \\
\text { variances } \\
\text { assumed }\end{array}$ & 5.146 & 0.036 & -9.44 & 18 & .000 & -0.052 & 0.006 & -0.064 & -0.040 \\
\hline
\end{tabular}




\begin{tabular}{|c|c|c|c|c|c|c|c|c|c|c|}
\hline & $\begin{array}{l}\text { Equal } \\
\text { variances } \\
\text { not } \\
\text { assumed }\end{array}$ & & & -9.44 & 14.480 & .000 & -0.052 & 0.006 & -0.064 & -0.040 \\
\hline \multirow[t]{2}{*}{$\begin{array}{l}\text { Globalization } \\
\text { index }\end{array}$} & $\begin{array}{l}\text { Equal } \\
\text { variances } \\
\text { assumed }\end{array}$ & 0.568 & 0.461 & -4.53 & 18 & .000 & -5.603 & 1.236 & -8.199 & -3.007 \\
\hline & $\begin{array}{l}\text { Equal } \\
\text { variances } \\
\text { not } \\
\text { assumed }\end{array}$ & & & -4.53 & 17.213 & .000 & -5.603 & 1.236 & -8.208 & -2.998 \\
\hline
\end{tabular}

The results of Levene's Test of equality adopted for this study is illustrated in (Table 3) as well. Using the Levene's Test for Equality of Variances, we assume a $5 \%$ p-value.

In relation to GDP, as indicated by Levene's Test for Equality (Table 3), shows a value of 0.001 indicating that we reject Null hypothesis that is $\mathrm{P}<0.05$, which suggests the variance of the two groups are not equal. Economic growth also recorded a 0.004 p-value which is less than 5 percent suggesting that, the variance of the two groups are not equal, so we reject Null hypothesis.

Table 2 also shows a value of 0.021 for Inflation which means we reject the Null hypothesis that is $\mathrm{P}<0.05$, and conclude that, the variance of the two groups are not equal. The application of the Levene's Test for Equality of Variances on Balance of trade shows a p-value of 0.951 which is greater than the $5 \%$. This indicate that re accept Null hypothesis that is $\mathrm{P}>0.005$ and that the variance of the two groups are equal. FDI which happens to be the next variable to Balance of payment on Table 2 shows a p-value of 0.036 . The value which is less than $5 \%$ also indicate a rejection of the Null hypothesis. This suggests that, the variance of the two groups are not equal. The last variable, Globalization index, also revealed a p-value of 0.461 greater than the 5\% signifying that the variance of the two groups are equal. We therefore accept the Null hypothesis, thus, $\mathrm{P}>0.05$ and conclude that the variance of the two groups are equal as far as Globalization index in concerned.

\section{Conclusion and Recommendation}

\subsection{Conclusion}

The importance of Currency Redenomination in Ghana is an arguable one and scholars are still studying. Some argue politically whilst others argue objectively and empirically. The study which aimed at establishing the impact of currency redenomination on the Ghanaian economy revealed the following. The economic variables used for the study are Gross Domestic Product (GDP), Economic growth, Inflation, Balance of Trade (BOP), foreign direct investment (FDI) and Globalization index.

The independent sample t-test conducted to ascertain the level of significance of the mean difference produced the results as follows: There is significant improvement in the performance of GDP, Inflation, Balance of trade, foreign direct investments and globalization as shown in the respective tables. There is however an increment in Economic growth, but the result showed an insignificant value.

Based on the findings above, the study concludes that the 2007 currency redenomination exercise has helped the Ghanaian economy by all standards. Notwithstanding the immediate issues associated with the exercise and those raised by political opponents and some citizens, this study concludes that, in the long run, redenomination of currency is beneficial to an economy's growth. The time value of money pave way for devaluation of currency as inflation catches up. As a result, policies like redenomination of currencies are to be applied when necessary to help curb inflation and save the country's monetary value to be competitive in the international market.

\subsection{Recommendation}

Though currency redenomination is able to curb inflation and help a country recover from certain losses and get back to its feet, but it must however be known that this exercise only curbs the problem but does not uproot it. It is therefore recommended that, governments of Ghana initiates policies that will help the boost economy's production and increase exports. Many advanced countries are boosting their locally made products to increase their exports. With the advancement of technology and its application, countries like Ghana with rich natural resource and raw materials must develop the manufacturing sector to process these raw materials for the international market. With this, the country will be able to depend on its local productions and reduce importation of similar products. This will subsequently reflect a favorable and positive balance of trade since our 
exports will exceed imports and our GDP will increase as well. Inflation will be controlled automatically in the process because we won't need the foreign currencies so much to trade, boosting our purchasing power parity and making our currency competitive around the globe. Also due to the role of the banking sector in currency circulation and transactions, just as Obuobi et al (2020) wrote, it is recommended that sufficient regulatory measures be put in place to ensure the smooth running of the banking sector in Ghana and erase the rotten ones for effective and efficient banking industry.

\section{Conflicts of Interest}

The authors declare no conflicts of interest regarding the publication of this paper.

\section{Reference}

Bank of Ghana. (2007). The redenomination of the Cedi. Retrieved from www.ghanacedi.gov.gh

Bank of Ghana. (2008). A brief history of the Ghanaian cedi. Retrieved from www.bog.gov.gh

Cohen, B. (2004). The Future of Money. Princeton University Press, Princeton.

Euphrasia, S. S., \& Sri, W. H. (2012). Impact of redenomination on economic indicators. International conference on Eurasian Economies 2012, 18-22. https://doi.org/10.36880/C03.00395

Francis, K. A. A., \& Emmanuel, K. M. (2014). Research journal's Journal of Accounting, 2(1).

International Monetary Fund. (2003). Lessons from the Crisis in Argentina. Retrieved from http://www.imf.org/external/np/pdr/lessons/100803.pdf

Ioana, D. (2005). The national currency re-denomination experience in several countries: A comparative analysis. SSRN Electronic Journal, 99-120. Retrieved from http://papers.ssrn.com/sol3/papers.cfm?abstract_id=1347407

Libor, Ž., \& Michal, C. (2015). Asian Economic and Financial Review, 5(6), 908-914. https://doi.org/10.18488/journal.aefr/2015.5.6/102.6.908.914

Martinez, I. (2007). Reflections from Latin America: Can new currency abate Venezuelan inflation, library of economics and liberty. Retrieved from http://www.econlib.org/

Mosley, L. (2005, September). Dropping zeros, gaining credibility? Currency redenomination in developing nations. In annual meeting of the American Political Science Association (pp. 1-26). Retrieved September 23, 2010, from http://convention2.allacademic.com/

Obuobi, B., Nketiah, E., Awuah, F., \& Amadi, A. G. (2020). Recapitalization of Banks: Analysis of the Ghana Banking Industry. Open Journal of Business and Management, 8, 78-103. https://doi.org/10.4236/ojbm.2020.81006

Özçay, A. (2006). New Turkish Lira. Retrieved November 22, 2019 from http://www.tcmb.gov.tr/yeni/banka/yenilira/NewTurkishLira.pdf

Schuler, K. (2008). Tables of Monetary Systems: Ghana. Retrieved May 15, 2013, from http://users.erols.com/kurrency

Tarhan, S. (2006). The New Turkish Lira. Retrieved from www.econ.umn.edu/tarhan

Woodruff, D. (1999). Money Unmade. Ithaca: Cornell University Press.

\section{Copyrights}

Copyright for this article is retained by the author(s), with first publication rights granted to the journal.

This is an open-access article distributed under the terms and conditions of the Creative Commons Attribution license (http://creativecommons.org/licenses/by/4.0/). 